\title{
Gökçeada - a Turkish island on the Thracian Sea
}

\author{
Gökçeada - turecka wyspa na Morzu Trackim
}

\section{Marek W. Lorenc}

Wrockaw University of Environmental and Life Sciences, Institute of Landscape Architecture, pl. Grunwaldzki 24a, 50-363 Wrocław, Poland, marek.lorenc@up.wroc.pl
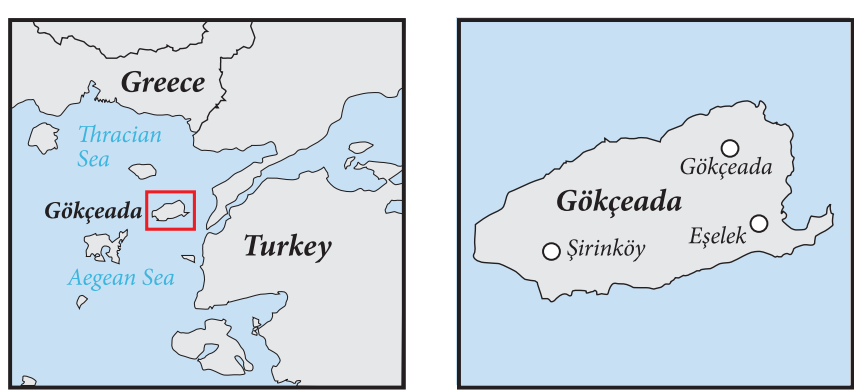

Abstract: Gökçeada is the biggest of all Turkish islands situated on the Thracian Sea about $20 \mathrm{~km}$ west of the Gallipoli Peninsula. Archaeological discoveries have so far indicated that colonization on this island dates back to 3000 BC. Currently, about 8300 people live on Gökçeada, including about 250 inhabitants of Greek origin. The diversity of the island's geological structure affects its rich relief and area colouring. Cliffs on the northern coast and beaches on the southern one, high mountains and deep canyons in the central part of the island attract fans of solitude, diving and nature. Monuments from the time of the Roman Empire are rare on the island. One of them is a huge rock with two tombs hewn out in it. It is located in a completely uninhabited and treeless area.
There are seven old plate trees on the island registered as natural monuments. The youngest one is 180 years old and the oldest tree is almost 630 years old.

Key words: Gökçeada, İmroz, Thracian Sea, Turkey, geotourism

Treść: Gökçeada jest największq spośród wszystkich tureckich wysp, położona na Morzu Trackim, w odległości około $20 \mathrm{~km}$ na zachód od Pólwyspu Gallipoli. Dotychczas uzyskane znaleziska archeologiczne wskazuja, że osadnictwo na tej wyspie sięga tu 3000 lat p.n.e. Obecnie na Gökçeadzie mieszka około 10000 osób, w tym okolo 250 pochodzenia greckiego. Zróżnicowana budowa geologiczna wyspy wplywa na bogata rzeźbę i koloryt terenu. Klifowe wybrzeże pótnocne i plaże wybrzeża południowego, a także wysokie góry i głębokie wąwozy centrum wyspy przyciagają amatorów samotności, zwolenników płetwonurkowania i wielu miłośników przyrody. Zabytki z czasów panowania Imperium Rzymskiego nie są na wyspie częste. Jednym z nich jest duży blok skalny z wykutymi w nim dwoma grobowcami, spoczywajacy na całkowicie bezludnym i bezdrzewnym terenie. Na terenie wyspy istnieje siedem starych platanów zarejestrowanych jako pomniki przyrody. Najmłodszy z nich ma 180 lat, a egzemplarz najstarszy - prawie 630.

Slowa kluczowe: Gökçeada, Imroz, Morze Trackie, Turcja, geoturystyka

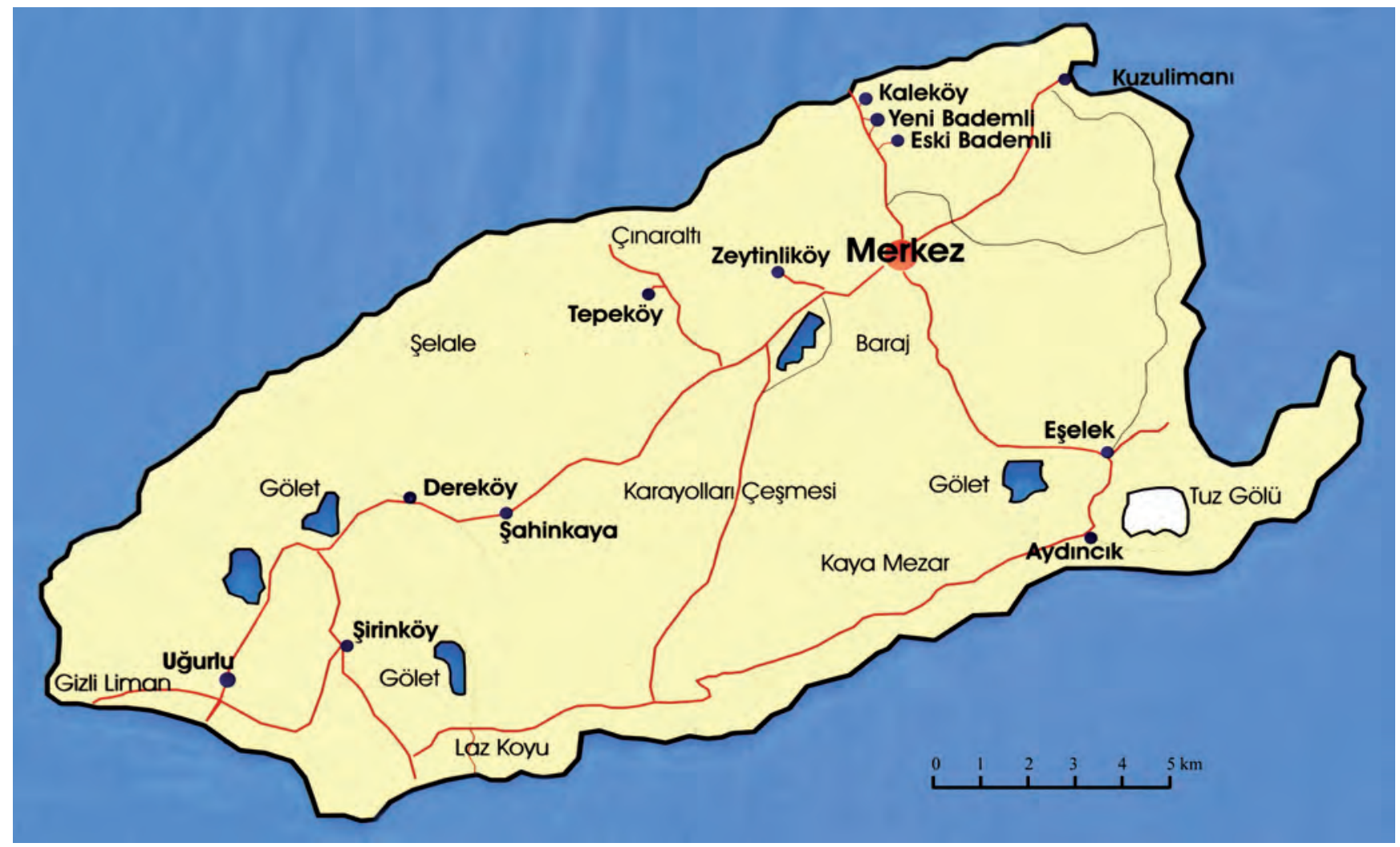

Fig. 1. Map of the Gökçeada (according to Gökçeada, 2002) • Mapa wyspy Gökçeada (wg Gökçeada, 2002) 


\section{Introduction}

Gökçeada, formerly named as Imbros and later as İmroz (deriving from the Greek Imvros), is the biggest of all Turkish islands (area of $289 \mathrm{~km}^{2}$, coastline of $69 \mathrm{~km}$ ) situated on the Aegean Sea, more precisely in its part called the Thracian Sea, $20 \mathrm{~km}$ west of the Gallipoli Peninsula. This peninsula, which is the entrance to the Dardanelles strait, has been known for heavy fighting during World War I. Administratively, the island belongs to the Çanakkale province and can be reached by ferry from Kabapete harbour located on the western coast of the above-mentioned Gallipoli Peninsula or via a direct but longer route from Çanakkale. In both cases the cruise ends at Kuzulimanı harbour located at the north-east edge of the island (Fig. 1, 2). There are neither permanent inhabitants nor any villages; therefore, it is almost an uninhabited place. Transport from the centre of the island may be inconvenient; however, visitors without their own means of transport can solve this problem by using a well-organised system of minibuses related to the timetable of ferries.

The only main road from Kuzulimanı harbour leads to Merkez (officially known as Gökçeada) located 4 km away in the south-west direction which is the only town on the island and also the local administrative centre. The general number of permanent inhabitants of the island amounts to about 8300 people, however, almost half of them live in Merkez. The remaining live in 13 villages and in small farms dispersed throughout the island. Among the permanent inhabitants of the island there are elders, Greek islanders, newcomers from Trabzon province on the eastern coast of the Black Sea, a few persons from Sparta region on the Aegean Sea, immigrants from Bulgaria and previous prisoners. The latter ones make up a significant percentage of the population because of a definite closure in 1990 of a semi-open prison established on the island in 1960. Moreover, there are workers of civil service, families of military staff and those who have given up their lives in big cities and have decided to settle down permanently on the island.

The aim of this paper is to describe a very poorly known Turkish island, which both geological structure and tectonic setting make it extremely interesting place to study. This is also a place with great potential for tourism in general and particularly for geoturism, that recently does not exist right there.

\section{History}

The oldest history of Gökçeada has not been discovered entirely yet. Archaeologists pin high hopes on completing excavations which have been carried out systematically from 1996 on Yeribademli Höyük hill. The discoveries carried out up to now indicate that colonization here dates back to the time of Troy I but there are traces of older colonization dated back to 3000 BC. At the same time excavations carried out on Crete in Knossos have confirmed that the old Greek name of the island - Imvros was known in the second millennium BC.

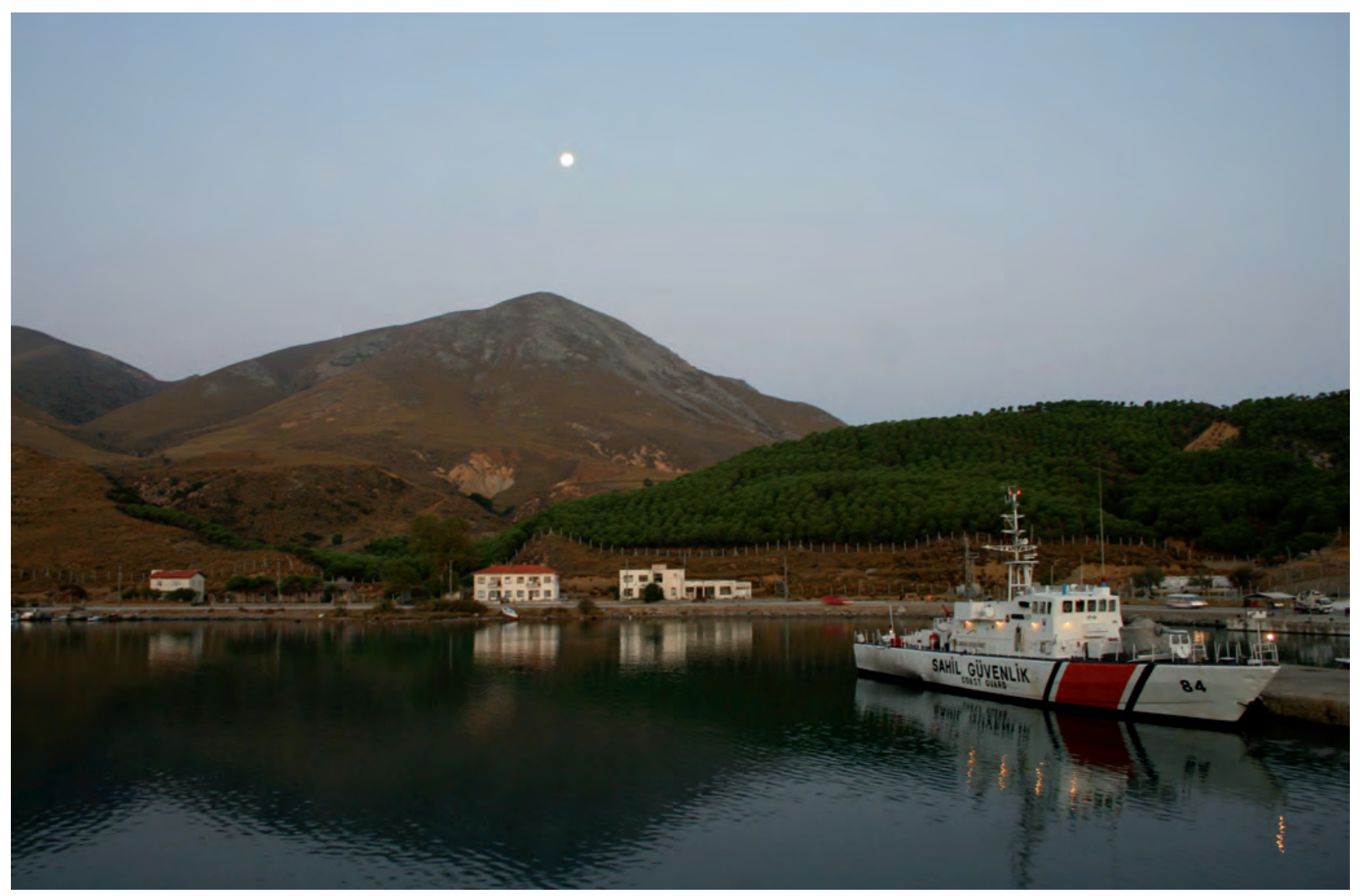

Fig. 2. Kuzulimanı - ferry harbour at dawn, phot. M.W. Lorenc • Kuzulimanı - przystań promowa o świcie, fot. M.W. Lorenc 
The oldest archaeological discoveries come from the surroundings of Uğurlu - neolithic handmade bowls with black and red inside, flat round buttons and unidentified objects in the shape of the letter 'S' (Andreou, Andreou, 1991, 2002). In the same area more objects were found - polished black, grey, red and dark-brown shells from the early Bronze Age and also ceramics from the late Bronze Age (Harmankaya, 2001).

Gökçeada can be found also in ancient literature in relation to Darius - the king of Persia (515 BC) or Miltiades - a son of Kypselos from Athens (494 BC) as well as to wars from 450446 BC. It appeared in works of Herodotus and Homer who placed Poseidon's stables near this island. According to Greek mythology, the area of Gökçeada was the location of the palace of Thetis, Achilles' mother (Hüryilmaz, 2002, 2002a).

Monuments from the time of Byzantium and the Roman Empire are rare on the island, however, some of them, for example tombs hewn out in rock, make a strong impression (Ousterhout, Held, 1997).

The latest history of the island is very complicated and because of its strategic position near the Dardanelles strait the island belonged in turns to Turkish or Greek territory. At the end of the Balkan wars (1913) the island, called then Imbros, belonged to the Ottoman Empire. In 1920 it was returned to Greece (as Imvros) but just after three years the island became again a part of Turkey despite the fact that most of its population was Greek. Most of Greek inhabitants left in the 1920s, others in 1974 during the Cyprian conflict. Houses abandoned by them are still in a very good condition because during the summer season their owners return to spend holidays there and visit places of their youth. Currently, there are 250 Greeks living here, however, most of them are advanced in years.

\section{Geology}

Gökçeada is quite a young geological structure located near an active edge of a lithospheric plate and Anatolian dislocation zone of transform faults. The island is made mainly from sedimentary rocks and volcanic rocks from the Tertiary period (Fig. 3), that is Eocene limestones and mudstones as well as mudstones and sandstones from the Oligocene. Upper Oligocene andesites were introduced into this set of sedimentary rocks. The south-east of the island is built from conglomerates of the youngest Oligocene. In the middle Miocene (15-10 Ma) the whole area was uplifted and started to be eroded. Its subsidence and sedimentation of mud sediments took place in the late Miocene. After the Pliocene this area was again uplifted and at that time the process of forming its current relief started (Öztürk, Hanilçi, 2002).

The oldest unit of Gökçeada built from arenaceous shales is revealed on the north-west coast of the island where one can find pink rocks, very clearly arranged in layers containing fossils (nummulites). At the point of contact with andesite these rocks reveal distinct changes resultant from contact metamorphism.

Eocene limestones rich in fossils are revealed in the central zone of the island's western part. They are biochemical, white and cream sediments of shallow and warm sea.

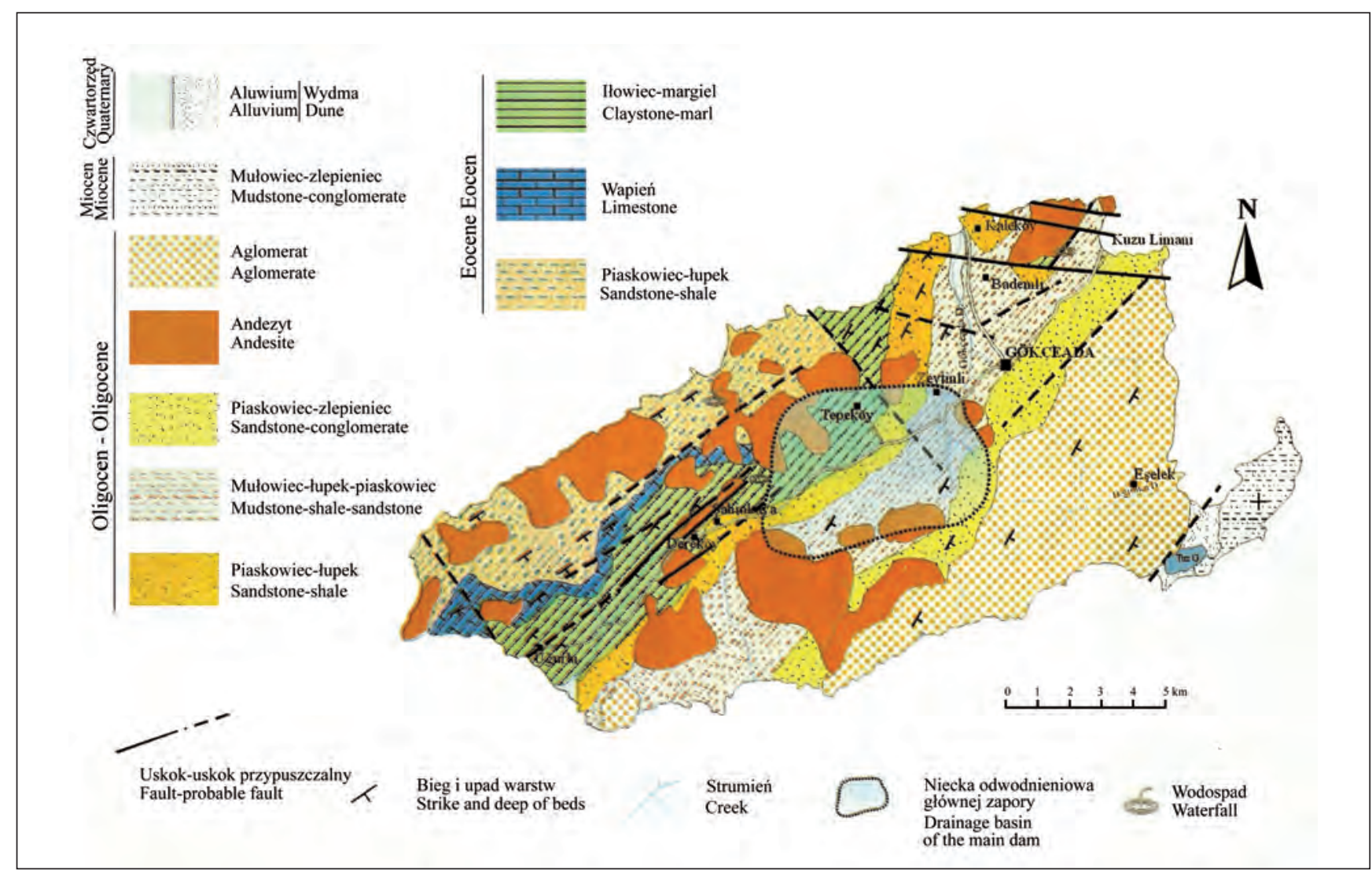

Fig. 3. Geological map of the Gökçeada island (Öztürk H., Hanilçi N., 2002) • Mapa geologiczna wyspy Gökçeada (Öztürk H., Hanilçi N., 2002) 
Nummulitic lenses of $5 \mathrm{~cm}$ thickness are visible to the naked eye. Limestones particularly rich in nummulites (Nummulites perforatus, Nummulites irregularis) become violet. Locally it is also possible to find big oyster fossils (Ostrea gigantica) of diameter up to $15 \mathrm{~cm}$ in limestones. At the south-east border of the limestone area there are claystones and marls of thickness up to $400 \mathrm{~m}$ (Akartuna, 1980).

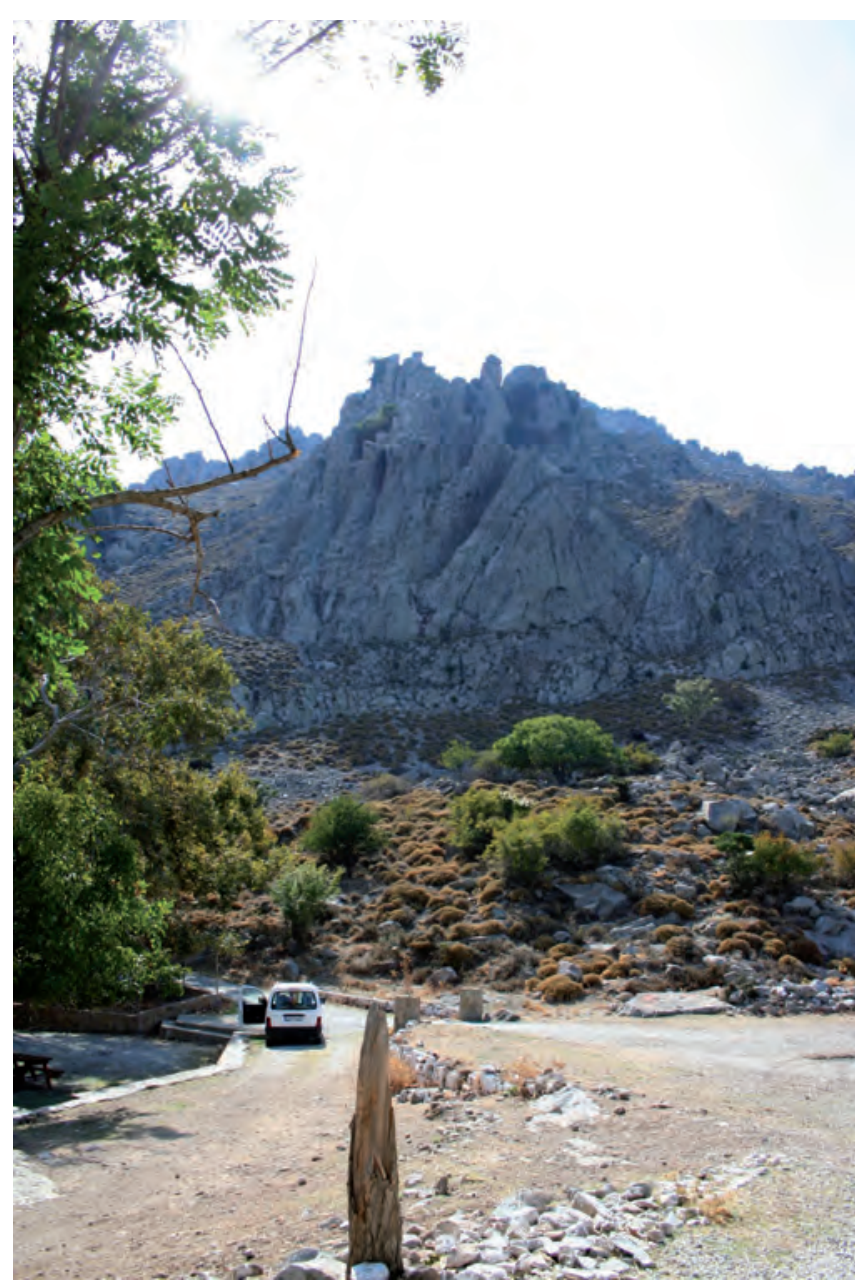

Fig. 4. Eski Bademli - andesitic dome, phot. M.W. Lorenc • Eski Bademli - kopuła andezytowa, fot. M.W. Lorenc

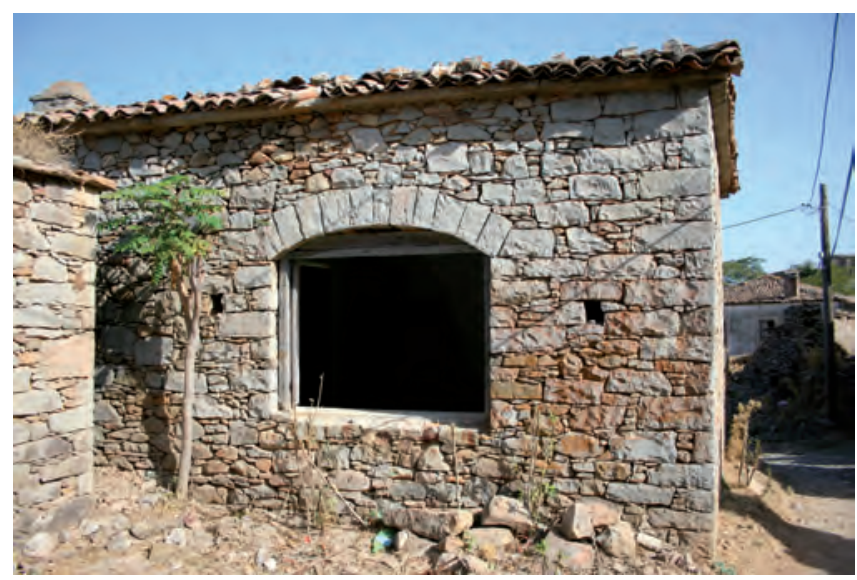

Fig. 5. Dereköy - building made from well fit blocks of andesite, phot. M.W. Lorenc • Dereköy - budynek wykonany z dobrze dopasowanych bloków andezytu, fot. M.W. Lorenc
The sedimentary formation of clastic rocks mainly consists of sandstones, slates and conglomerates which are revealed in the central part of the island. These sediments were deposited on limestones after marine regression in the Eocene. Cross stratification and current structures clearly visible in these rocks (including thick conglomerates) indicate sedimentation in the river or delta environment. Thicker horizons of lignite in this formation also support the fluviatile paleoenvironment. The thickness of this whole clastic formation reaches up to $1 \mathrm{~km}$.

The above clastic series is covered by a series composed of mudstones, slates and sandstones from the late Oligocene of brown and green colour which were deposited in a delta environment during temporary subsidence of this area. These rocks reveal themselves as a zone running through the axial part of the island from Kuzulimanı in the north-east to Laz Koyu in the south-west.

Chronologically, the rock-package consists of sandstones clearly in layers and conglomerates reflecting the uplift of the area at the end of the Oligocene. These rocks stretch as a $2 \mathrm{~km}$ wide zone in the NE direction of the line Kuzulima$\mathrm{nl}$ - Incir Burnu.

The set of the youngest sedimetary rocks is represented by mudstones and conglomerates which were laid down at the turn of Miocene and Pliocene. It is revealed in the south-east of the island which forms a peninsula in the area of Tuz Gölü salty lake.

Volcanites represented by cream and greenish hornblendic and augite andesites were dated by using the K/Ar method to 34.3 and $30.4 \mathrm{Ma}$, that is the early Oligocene (Ercan et al., 1995). There are more than 10 volcanic pipes. A small but very representative volcanic dome is located in the region of Kaşkaval in the northen part of Kuzulimanı (Fig. 4).

Columnar reparability of andesitic lava is very characteristic for this type of rocks and strong cracking of the whole structure enables infiltration of rain water which at the border with rocks rich in silty minerals gets out in the form of numerous springs. It is worth mentioning that Gökçeada is a huge reservoir of sweet water transported even to the near Turkish and Greek islands suffering from its shortage. On the whole island andesite has been always used as a very good and resistant building material (Fig. 5). A vast, $50 \mathrm{~m}$ wide zone of contact transformations formed at the point of contact with mudstones and sandstones. Greenish-white rocks formed in this zone, in comparison with the initial rocks, significantly harder.

Agglomerates and tuffs are a different volcanogenic formation, they represent the pyroclastic fall after an eruption of an andesitic stratovolcano in the Oligocene and occupy the whole south-east corner of the island starting from the line Kuzulimanı - Incir. These products consist of blocks of andesite of $15 \mathrm{~cm}$ diameter joined together with volcanic ash. In extreme cases these blocks can be even of $2 \mathrm{~m}$ diameter. Weathering and erosion of ash cement by wind and rain cause that at the surface of agglomerates there are residual concentration of blocks on the coast and also at the sea bottom (Öztürk, Hanilçi, 2002).

The island of Gökçeada originated in a very active tectonic zone connected with the North Anatolian Fault which 
has the character of normal fault and is responsible for many earthquakes in this area. The tectonics of the island is marked with a series of faults whose dip is diagonal in relation to the extension of the island. These faults were very active within the past 10000 years. Moreover, normal faults are found in the northern part of the island in the area of Kaşkaval Kaleköy. One of the results of their activity causing earthquakes was the destruction of a historical castle on the hill of Kaleköy. Many springs of drinking water are found along the same tectonic zone. Ore mineralization in the area of Gökçeada village is also related to the occurrence of faults. A concentration of iron in the form of limonite was discovered there as well as a concentration of manganese oxides in the form of pyrolusite and psilomelane. However, these concentrations are not considered as sources of economic value (Öztürk, Hanilçi, 2002).

\section{Tourist attractions}

Gökçeada is an island elongated in the NE-SW direction. Most faults and borders of outcrops of geological units run conformably with the island's extension. However, the northern and southern coasts of the island have a different character as a result of active tectonics. The biggest faults are found in the northern part of the island and they are related to the occurrence of the North-Anatolian Fault in the Aegean Sea. Their activity caused partial tilting of the whole island to the south. As a consequence, steep cliff coast occur in the north, whereas in the south there are sandy beaches gently falling into the sea.

The first impression given by the coast in the area of Kuzulimanı harbour is quite gloomy as nearby cliff and hills present bare rocks without trees (Fig. 6). However, it is not a typical landscape for the whole island. A fertile soil enables to cultivate different agricultural products on the island.

The rocky cliff of Kaşkaval spreading to the west of Kuzulimanı harbour, which can be seen from the sea, is built from interbeddings of sandstones, mudstones and slates. Longterm erosion and selective weathering processes created a form resembling a pile of cheese slices. Since big numbers of goats and sheep have been always kept on the island, there is of course a legend related to this place and cheese. The common name of this place - "Cheese Rocks" seems relevant as from here originates the name of a cheese type popular also in Poland - "Kashkaval".

Many ship wrecks from the times of World War I can be found on the sea bottom round Kuzulimanı causing danger for sailors and attracting fans of diving. Despite the fact that Gökçeada is very popular among scuba divers, there is not an organised centre for fans of this sport. The first Turkish Underwater National Park has been established here - its spreads as a $200 \mathrm{~m}$ long piece of coast starting from Yıldızköy up to Yelkenkaya.

When approaching Gökçeada by ferry, the place may seem an inhospitable and rocky island. In reality, it is beautiful and green in a large part. A visit to Gökçeada leaves unforgettable impressions.

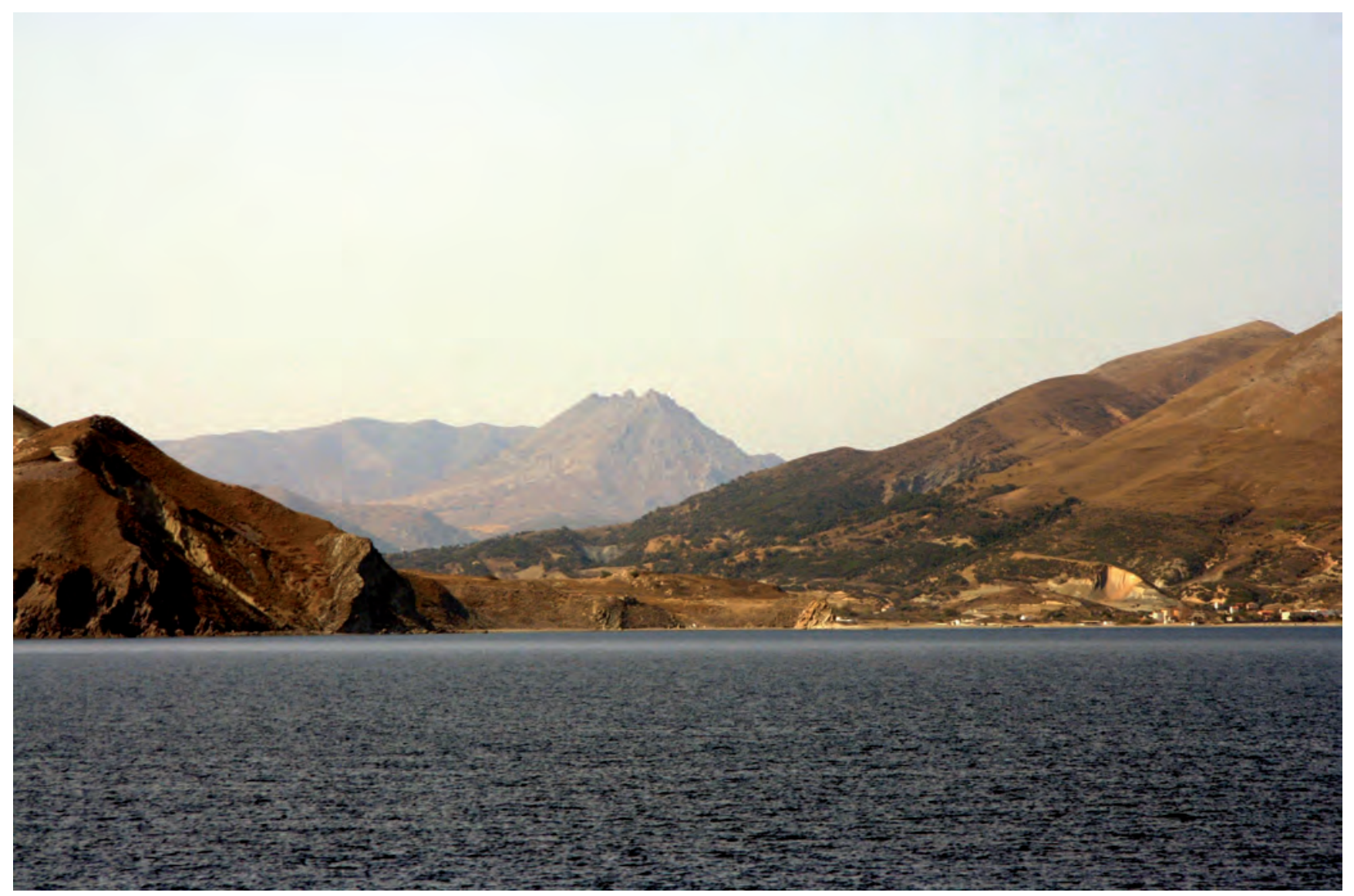

Fig. 6. Kuzulimanı - rocky coast of sandstones with andesitic dome in the background, phot. M.W. Lorenc • Kuzulimanı - skaliste piaskowcowe wybrzeże z andezytową kopułą w tle, fot. M.W. Lorenc 
In its centre there are woods where pines, cedars and hornbeams prevail. Two endemic species live here: jujube, which gives fruit similar to wild olive, and dogwood. There are many old olive groves and vineyards because the island is famous for the production of oil and wine. Numerous types of fruit trees are grown in gardens next to houses (including quince).

There are seven old trees registered as monuments of nature. All of them are plane trees, the youngest ones are 180 years old and others are 400 years old. The oldest tree (Fig. 7) is

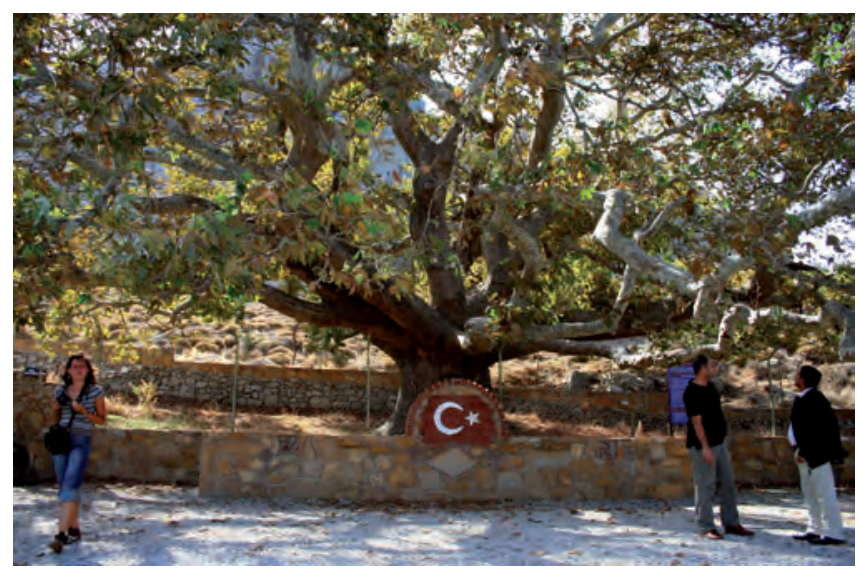

Fig. 7. Eski Bademli - plane tree -630 years old natural monument, phot. M.W. Lorenc - Eski Bademli - platan - pomnik przyrody liczący około 630 lat, fot. M.W. Lorenc almost 630 years old and grows in the area of Eski Bademli located about $3 \mathrm{~km}$ to the north of Merkez. A marvellous view of the northern coast built from sandstones and andesites (Fig. 8) unfolds there.

Just $4 \mathrm{~km}$ away to the north of Eski Bademli there is a place called Kaleköy divided into two parts: the modern coastal one which is inhabited and a hill situated $10 \mathrm{~km}$ away where today we can see the above-mentioned ruins of an old castle-citadel. The total destruction of the castle took place after one of the historic earthquakes caused by movements at the North Anatolian Fault.

Going $3 \mathrm{~km}$ to the west of Merkez, it is worth stopping over at a little village called Zeytinliköy which is located on a gentle slope and surrounded by ancient olive groves (Fig. 9). A little bit to the west, $7 \mathrm{~km}$ away there is another village - Tepeköy established on a hill with a beautiful view of other surrounding hills and a barrier lake with turquoise water.

One of the oldest villages is Dereköy located in the centre of the island's western part in a distance of $15 \mathrm{~km}$ to the west of Merkez. During its time of splendour there were 600 houses in the village (according to some sources even 10000 inhabitants). The inhabitants, who came mostly from the area of the Black Sea, lived on agriculture and bee-keeping. Nowadays, the village is almost deserted and it is protected legally in whole.

Characteristic landscapes in the southern part of the island are vast, sandy beaches stretching to the east of Uğurlu (Fig. 10).

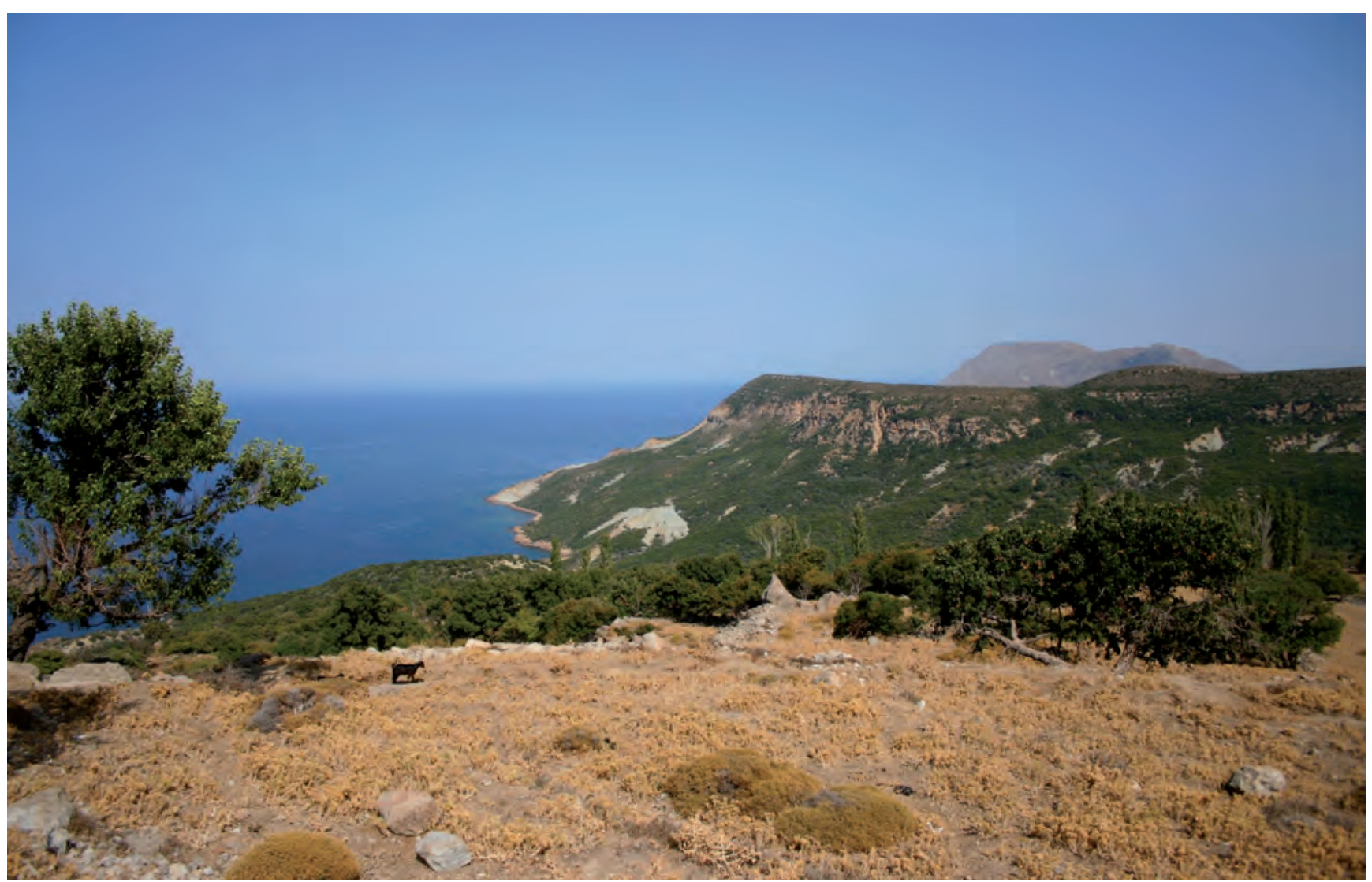

Fig. 8. Eski Bademli - panorama of the northern coast built from andesites (first and third layer) and sandstones (second layer), phot. M.W. Lorenc • Eski Bademli - panorama północnego wybrzeża zbudowanego z andezytów (pierwszy i trzeci plan) i piaskowców (drugi plan), fot. M.W. Lorenc 


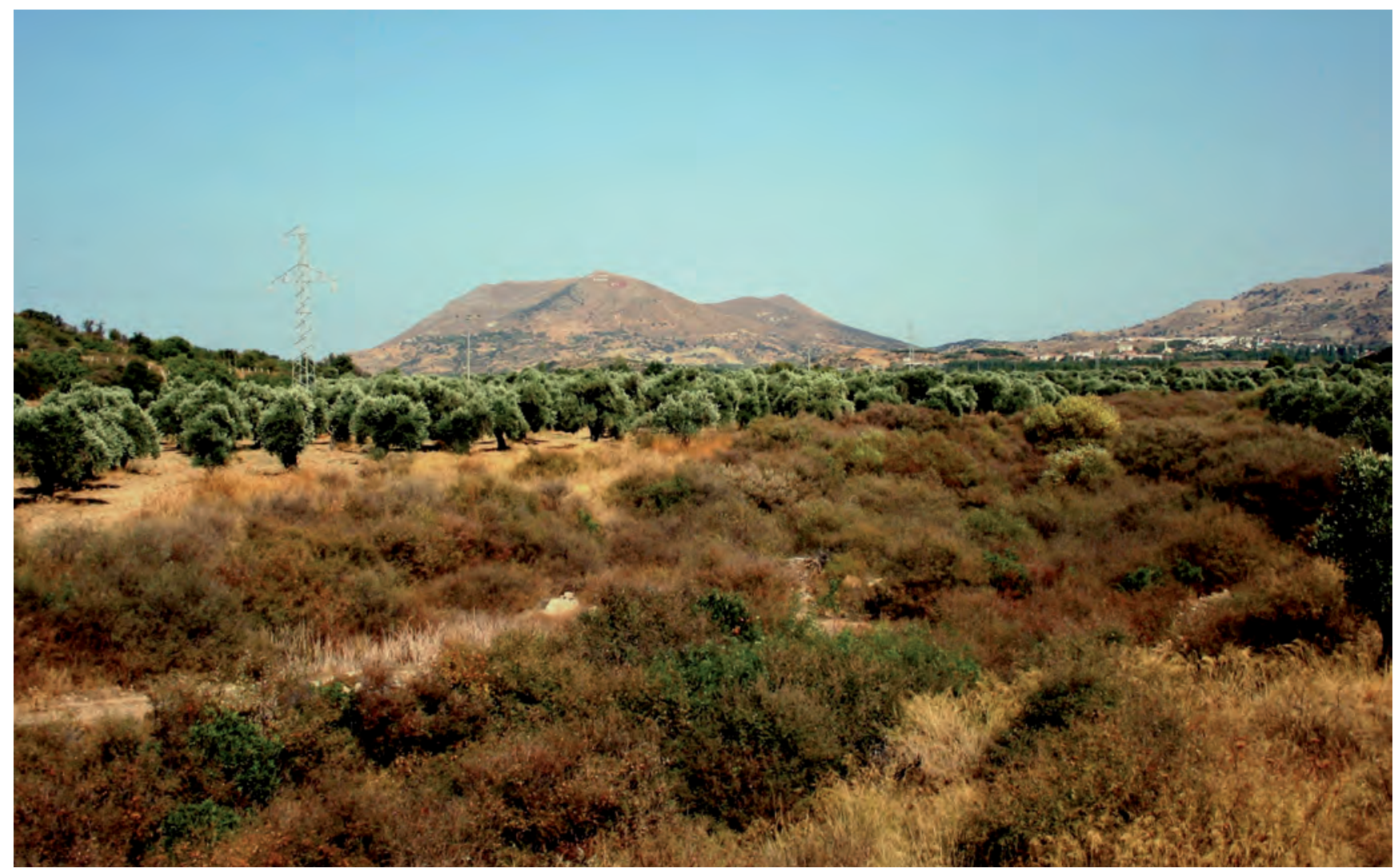

Fig. 9. Zeytinliköy - olive grove of several years, phot. M.W. Lorenc • Zeytinliköy - od wielu lat prowadzona plantacja drzew oliwnych, fot. M.W. Lorenc

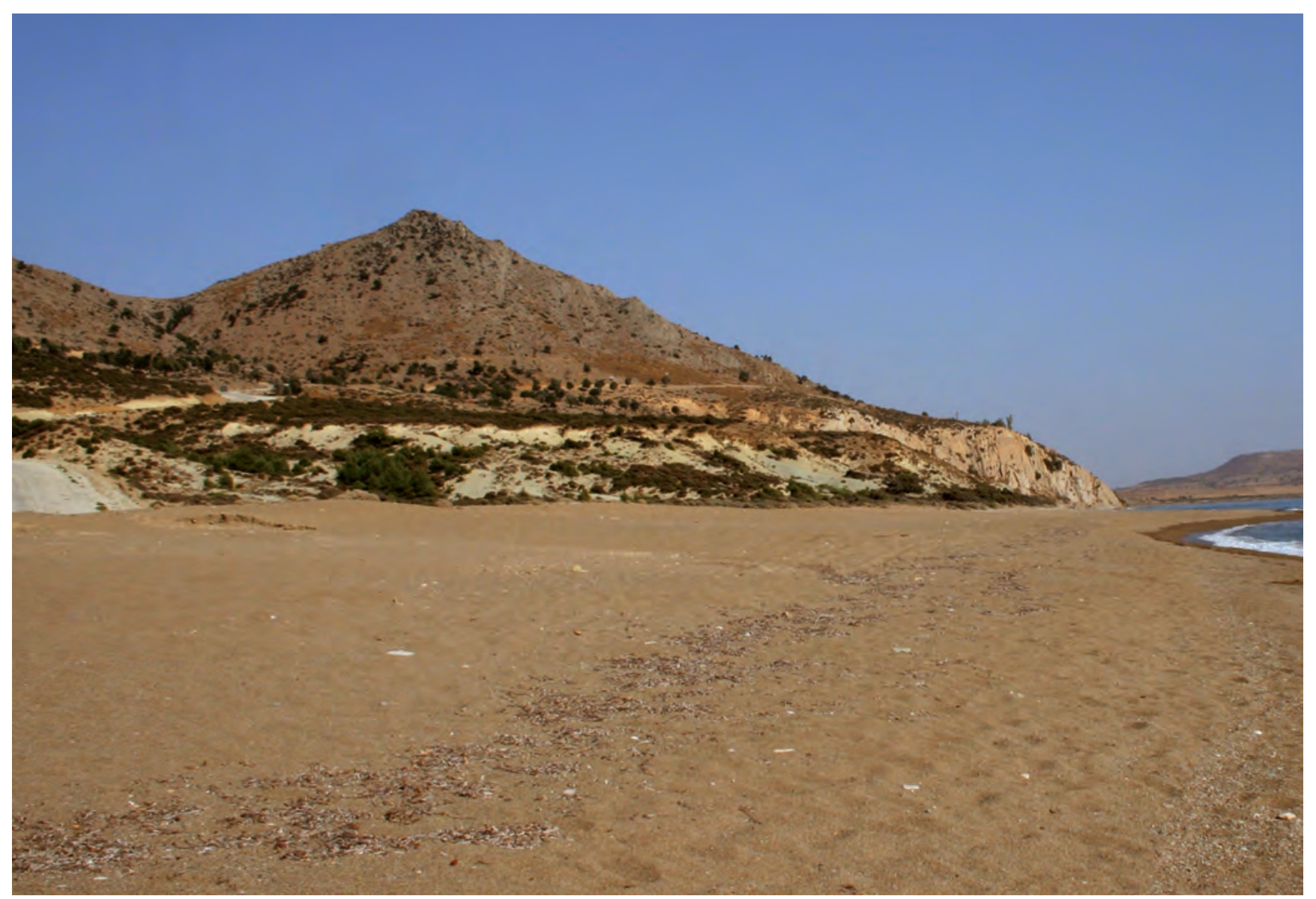

Fig. 10. Uğurlu - beaches of the southern coast, phot. M.W. Lorenc • Uğurlu - plażowe południowe wybrzeże wyspy, fot. M.W. Lorenc 


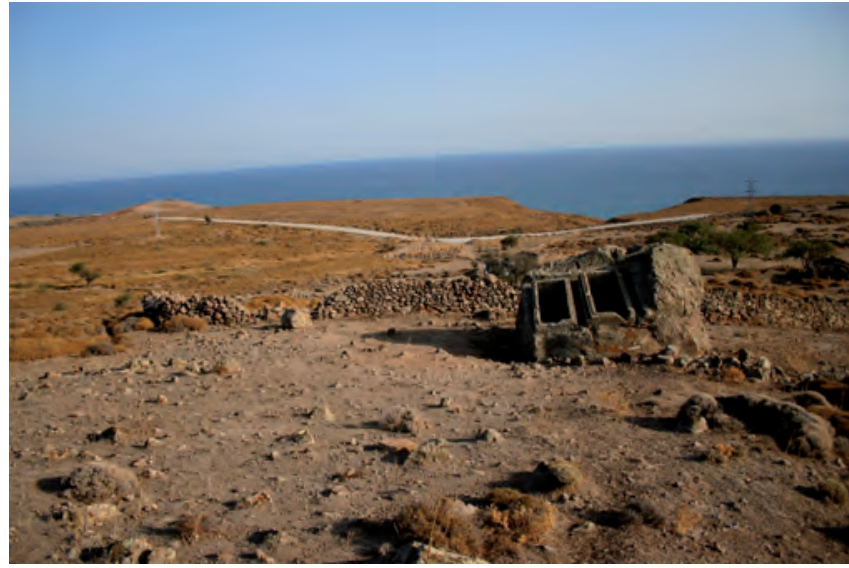

Fig. 11. Kokina - conglomerate block with two tombs from the time of the Roman Empire, phot. M.W. Lorenc • Kokina - zlepieńcowy blok z podwójnym grobowcem z czasów rzymskich, fot. M.W. Lorenc

Going round the island further to the east, we will come across a place (although it can be easily overlooked) of a great historical value in the area of Kokina, $18 \mathrm{~km}$ away from Merkez. On a completely uninhabited and treeless ground there is a big piece of conglomerate with two tombs hewn out in it (Fig. 11). This object is dated back to the time of the Roman Empire.

About $5 \mathrm{~km}$ away to the east there is a village called Aydıncık. A salty lake - Tuz Gölü is located in its surroundings and it is separated from the sea with a low dune (Fig. 12). In the old times the lake provided a source of salt for the islanders. Mud from the lake has therapeutical values which are used by natives as well as tourists.

Apart from the capital of the island - Merkez, only three villages are inhabited in large numbers: Kaleköy, Zeytinliköy i Tepeköy. Others, although very interesting and picturesque, are considerably abandoned and destroyed. In their centres and outskirts we can meet half-wild wandering around donkeys and goats.

Fishing and tourism are two main branches of the island's economy. However, lack of big hotels and a not well organized tourism system both are reasons why most of tourists are individual. Moreover, a majority of them are those who prefer diving, windsurfing and kitesurfing. Geotourism does

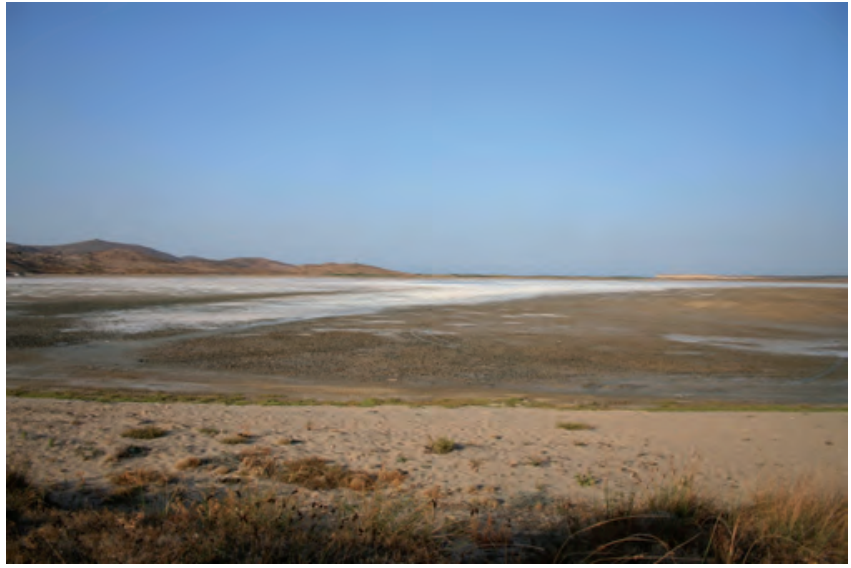

Fig. 12. Aydıncık - therapeutical mud of the salty lake, phot. M.W. Lorenc • Aydıncık - terapeutyczny muł słonego jeziora, fot. M.W. Lorenc

not exist here as a kind of tourism and those who want to visit places that could be called 'geo-sites', they have to organize their trips by their own way with a local guide.

\section{Summary}

Many small and large islands are included in the Turkish territory. The biggest one on the Aegean Sea is Gökçeada which in the past belonged to Greece and was called then Imvros. Diversified geological structure causes that the variety of rocks here affects the island's rich relief and area colouring. The cliff coast in the north and beaches in the south, and high mountains in the central island attract not only Turkish but also foreign tourists. Among them there are fans of solitude, enthusiasts of diving and lovers of nature - all of them will find a place for themselves on Gökçeada. Deserted villages make unforgettable impressions. Apart from monuments of architecture, we will find there very friendly, mainly elder people. Goats and donkeys living freely are a particular attraction. Recently the Turkish government has been allocating more and more funds for protecting and preserving many places and objects on the island. Travellers leaving the island by the first morning ferry which returns to Çanakkale (Fig. 2) will be impressed by the view of the island at dawn.

\section{Streszczenie}

\section{Gökçeada - turecka wyspa na Morzu Trackim}

\section{Marek W. Lorenc}

Gökçeada - dawniej nazywana Imbros lub İmroz - jest największą spośród wszystkich tureckich wysp, położoną na Morzu Egejskim, a dokładniej na jego części znanej jako Morze Trackie, w odległości około 20 km na zachód od Półwyspu Gallipoli. Administracyjnie wyspa należy do prowincji Çanakkale, a dostać się tam można promem z portu Kabapete, położonego na zachodnim wybrzeżu wspomnianego
Półwyspu Gallipoli, albo dłuższą trasą bezpośrednio z Çanakkale. W obu przypadkach prom kończy swój rejs w przystani Kuzulimanı, położonej na północno-wschodnim krańcu wyspy (Fig. 1, 2). Stąd jedyna główna droga prowadzi w kierunku południowo-zachodnim do leżącej w odległości około 4 km największej na wyspie miejscowości Merkez (oficjalnie znanej jako Gökçeada), będącej zarazem lokalnym centrum administracyjnym. Ogólna liczba stałych mieszkańców wyspy wynosi około 8300 osób, z czego prawie połowa mieszka właśnie w Merkez. Pozostali zamieszkują 13 wiosek oraz pojedyncze rozproszone gospodarstwa.

Historia osadnictwa na wyspie sięga 3000 lat, ale najstarsze znaleziska archeologiczne z okolic Uğurlu pochodzą z neolitu (Andreou, Andreou, 1991, 2002) oraz z wczesnej epoki brązu 
(Harmankaya, 2001). Zgodnie z mitologią grecką, w rejonie wyspy Gökçeada, znajdował się też pałac Tetydy, matki Achillesa (Hüryilmaz, 2002, 2002a). Zabytki z czasów Bizancjum i Imperium Rzymskiego nie są na wyspie częste, aczkolwiek niektóre z nich, jak na przykład kute w skale grobowce, robią duże wrażenie (Ousterhout, Held, 1997).

Wyspa Gökçeada zbudowana jest głównie ze skał osadowych i wulkanicznych trzeciorzędu (Fig. 3). Są to eoceńskie wapienie i mułowce oraz mułowce i piaskowce oligocenu. W ten pakiet intrudowały górno-oligoceńskie andezyty. Południowo-wschodnią część wyspy budują zlepieńce najwyższego oligocenu. W środkowym miocenie cały obszar został wypiętrzony i zaczął podlegać erozji, a w późnym miocenie nastąpiła jego subsydencja i sedymentacja osadów mułowych. Po pliocenie teren został ponownie wypiętrzony i od tego czasu zaczęła się formować jego obecna rzeźba (Öztürk, Hanilçi, 2002).

Najstarsza jednostka Gökçeady zbudowana z łupków piaszczystych odsłania się na północno-zachodnim wybrzeżu wyspy. Są to skały barwy różowej, bardzo wyraźnie warstwowane, zawierające skamieniałości (numulity).

Bogate w skamieniałości eoceńskie numulitowe wapienie odsłaniają się w centralnej strefie zachodniej części wyspy. Są to biochemiczne, białe i kremowe, osady płytkiego i ciepłego morza, zawierające widoczne gołym okiem soczewki numulitowe miąższości około 5 cm (Akartuna, 1980).

Kolejna osadowa formacja skał okruchowych składa się głównie z piaskowców, łupków i gruboławicowych zlepieńców, odsłaniających się w centralnej części wyspy. Osady te zostały zdeponowane na wapieniach po regresji eoceńskiego morza w warunkach sedymentacji w środowisku rzecznym lub deltowym.

Serię powyższą przykrywają mułowce, łupki i piaskowce późnego oligocenu, barwy brązowo-zielonej, które były deponowane w środowisku deltowym podczas okresowej subsydencji tego obszaru w osiowej części wyspy.

Kolejnym chronologicznie pakietem skał są wyraźnie warstwowane piaskowce i zlepieńce odpowiadające kolejnemu wypiętrzeniu terenu pod koniec oligocenu.

Pakiet najmłodszych skał osadowych reprezentują mułowce i zlepieńce, które osadzały się na przełomie miocenu i pliocenu w południowo-wschodniej części wyspy.

Wulkanity (Fig. 4) reprezentowane są przez hornblendowe i augitowe andezyty barwy kremowo-zielonkawej, które metodą K/Ar datowano na 34,3 oraz 30,4 M.A., czyli na wczesny oligocen (Ercan et al., 1995). Oddzielność słupowa andezytowej lawy jest bardzo charakterystyczna dla tego typu skał, a silne spękanie całej struktury umożliwia migrację w głąb wody opadowej, która na granicy ze skałami bogatymi w minerały ilaste wydobywa się na zewnątrz w formie licznych źródeł. Na terenie całej wyspy andezyt zawsze używany był jako bardzo dobry i wytrzymały materiał budowlany (Fig. 5).

Inną formacją wulkanogeniczną są aglomeraty i tufy reprezentujące opad piroklastyczny po erupcji oligoceńskiego andezytowego stratowulkanu, zajmujące całe południowo-wschodnie naroże wyspy (Öztürk, Hanilçi, 2002). Warto nadmienić, że wyspa Gökçeada jest potężnym rezerwuarem słodkiej wody, transportowanej nawet do pobliskich - tureckich i greckich - wysp, powszechnie cierpiących na jej niedobór.
Ta na pozór niegościnna i skalista wyspa (takie wrażenie sprawia widziana z promu zbliżającego się do przystani Kuzulimanı) w rzeczywistości jest piękna, w znacznej części zielona, a wizyta na niej pozostawia niezapomniane wrażenia.

Zaledwie 4 km dalej na północ od Bademli położona jest miejscowość Kaleköy, podzielona na dwie części: współczesną nadbrzeżną, zamieszkałą oraz oddalone o około1 km wzgórze, na którym znajdował się dawny zamek-cytadela, z którego do dziś zachowały się jedynie ruiny. Do jego całkowitego zniszczenia doszło po jednym z historycznych trzęsień ziemi wywołanych ruchami na uskoku północno-anatolijskim. W wielu miejscach na wyspie zupełnie nie ma drzew (Fig. 6), ale nie jest to krajobraz typowy dla całej wyspy. Gleba jest tu urodzajna i odpowiednia do uprawy różnych produktów rolnych. Na terenie wyspy istnieje kilka bardzo starych platanów mających status pomników przyrody. Najstarszy z nich (Fig. 7) ma prawie 630 lat i rośnie w okolicach Eski Bademli - wioski leżącej około 3 km na północ od Merkez. Stąd roztacza się też piękny widok na północne wybrzeże wyspy zbudowane z piaskowców i andezytów (Fig. 8).

Udając się z Merkez na zachód, w odległości zaledwie $3 \mathrm{~km}$ warto zatrzymać się w malutkiej wiosce Zeytinliköy, położonej na łagodnym stoku, otoczonej wiekowymi plantacjami oliwnymi (Fig. 9). Nieco dalej na zachód, w odległości 7 km, znajduje się kolejna wioska Tepeköy założona na wzgórzu, z którego roztacza się piękny widok na pozostałe okoliczne wzgórza, a także na jezioro zaporowe, którego woda ma barwę turkusową.

Jedną z najstarszych wiosek na wyspie jest Dereköy, położona w centrum zachodniej części Gökçeady, w odległości około 15 km na zachód od Merkez, która w czasach świetności liczyła 600 domostw. Jej mieszkańcy, pochodzący gównie z rejonu Morza Czarnego, utrzymywali się z rolnictwa i hodowli pszczół. Obecnie wioska jest prawie wyludniona i w całości objęta prawną ochroną.

Charakterystycznym krajobrazem południowej części wyspy są rozległe, piaszczyste plaże, ciągnące się na wschód od Uğurlu (Fig. 10). Wędrując wokół wyspy dalej na wschód, w regionie o nazwie Kokina, leżącym 18 km od Merkez, można trafić na miejsce o dużej wartości historycznej. Tutaj, na całkowicie bezludnym i bezdrzewnym terenie, spoczywa duży blok skalny z wykutymi w nim dwoma grobowcami. Obiekt ten datowany jest na czasy panowania w tym rejonie Imperium Rzymskiego (Fig. 11).

Około 5 km dalej na wschód znajduje się wioska Aydıncık, a w jej okolicach niewielkie i płytkie słone jezioro Tuz Gölü, oddzielone od morza niską wydmą, które w dawnych czasach było dla tutejszych wyspiarzy miejscem produkcji soli. Muł tego jeziora ma własności terapeutyczne, wykorzystywane do dziś zarówno przez tubylców, jak i turystów (Fig. 12).

Oprócz stolicy wyspy Merkez obecnie najliczniej zamieszkałe są tylko trzy wioski: Kaleköy, Zeytinliköy i Tepeköy. Pozostałe, jakkolwiek bardzo ciekawe i malownicze, w znacznym stopniu są opuszczone i częściowo zrujnowane, a w ich centrum i na peryferiach spotyka się na pół zdziczałe, wałęsające się tu i ówdzie osły i kozy. W ostatnich latach coraz większe środki finansowe rząd turecki przeznacza na zabezpieczenie i ochronę wielu miejsc i obiektów na wyspie. 
Te w znacznej mierze wyludnione wioski, w których oprócz zabytków architektury spotyka się bardzo życzliwych, przeważnie starszych ludzi, pozostawiają niezapomniane wrażenie. Nie mniejsze wrażania pozostawia sama wyspa widziana o świcie, kiedy to odpływa pierwszy powrotny prom w kierunku Çanakkale (Fig. 2).

Chociaż turystyka jest obok rybołówstwa drugą najważniejsza gałęzią gospodarki na wyspie, to jednak brak dużych hoteli oraz dobrze zorganizowanej turystyki sprawiają, że przyjeżdżają tu głównie turyści indywidualni. Znaczną ich większość stanowią miłośnicy nurkowania oraz windsurfingu i kitesurfingu. Pojęcie geoturystyki tutaj nie istnieje, a osoby zainteresowane taką właśnie formą turystyki zmuszone są do organizowania wycieczek do miejsc, które można by nazwać geostanowiskami, we własnym zakresie, najlepiej z lokalnym przewodnikiem.

\section{References (Literatura)}

Akartuna M., 1980. Imroz Adasinda Bazi Jeolojik Müșahadeler. Türkiye Jeoloji. Kurumu Bülteni, 2/2: 8-18.

Andreou I., Andreou Y., 1991. E Imvros sten Archaioteta. Archaiologia, 41: 92-100.

Andreou I., Andreou Y., 2002. The Imvros Island in the Early Bronze Age. Archaiologia, 82: 75-83.

Ercan T., Satir M., Steinitz G., Dora A., Sari-Fakioğlu E., Adis C., Walter H.J., ve Yildirim T., 1995. Biga Yarimadasi ile Gökçeada, Bozcaada ve Tavsan Adalanndaki Tersiyer Volkanizmansinin Özellikleri. MTA Dergisi, 117: 55-86.

Harmankaya S., 2001. Gökçeada Survey. In: Belli O. (ed.), Istanbul University's Contributions to Archaeology in Turkey (1932-2000). Istanbul University: 274-278.
Hüryilmaz H., 2002. Silent Witnesses of Imbros: Early Bronze Age Human Figurines from Yenimbademli. Festschrift für Manfred Korfmann, Mauerschau. In: Asian I.R. et al. (eds), Emshalden-Grunbach: 351-362.

Hüryilmaz H., 2002a. Archaeology of Gökçeada. In: Öztürk B. (ed.), Gökçeada, Gökçeada Belediyesi: 83-91.

Ousterhout R., Held W., 1997. Survey of the Ancient and Byzantine Monuments on Imbros / Gökçeada 1995. XIV, Araştirma Sonuçian Toplantsi II: 55-69.

Öztürk H., Hanilçi N., 2002. Geology of Gökçeada and its Natural Resources. In: Öztürk B. (ed.), Gökçeada, Gökçeada Belediyesi: 131-150. 